\title{
Evaluation of exposure biomarkers in offshore workers exposed to low benzene and toluene concentrations
}

\author{
Nancy B. Hopf · Jorunn Kirkeleit • Magne Bråtveit • \\ Paul Succop · Glenn Talaska $\cdot$ Bente E. Moen
}

Received: 13 December 2010/Accepted: 1 June 2011/Published online: 14 June 2011

(C) Springer-Verlag 2011

\begin{abstract}
Purpose Characterize ethylbenzene and xylene air concentrations, and explore the biological exposure markers (urinary $t, t$-muconic acid ( $t, t$-MA) and unmetabolized toluene) among petroleum workers offshore. Offshore workers have increased health risks due to simultaneous exposures to several hydrocarbons present in crude oil. We discuss the pooled benzene exposure results from our previous and current studies and possible co-exposure interactions.
\end{abstract}

\section{N. B. Hopf ( $\square)$}

Institut universitaire romand de Santé au Travail, Institut für Arbeit und Gesundheit, Institute for Work and Health (IST),

Rue du Bugnon 21, 1011 Lausanne, Switzerland

e-mail: Nancy.Hopf@hospvd.ch

\section{J. Kirkeleit · M. Bråtveit}

Occupational and Environmental Medicine,

Department of Public Health and Primary Health Care, University of Bergen, Kalfarveien 31, 5018 Bergen, Norway e-mail: Jorunn.Kirkeleit@isf.uib.no

\section{Bråtveit}

e-mail: Magne.Bratveit@isf.uib.no

\section{P. Succop - G. Talaska}

Department of Environmental Health,

University of Cincinnati College of Medicine,

PO Box 670056, Cincinnati, OH 45267-0056, USA

e-mail: SUCCOPPA@ucmail.uc.edu

G. Talaska

e-mail: TALASKGG@ucmail.uc.edu

\section{B. E. Moen}

Department of Occupational Medicine,

Haukeland University Hospital, 5020 Bergen, Norway

e-mail: Bente.Moen@isf.uib.no
Methods BTEX air concentrations were measured during three consecutive 12-h work shifts among 10 tank workers, 15 process operators, and 18 controls. Biological samples were collected pre-shift on the first day of study and postshift on the third day of the study.

Results The geometric mean exposure over the three work shifts were $0.02 \mathrm{ppm}$ benzene, $0.05 \mathrm{ppm}$ toluene, $0.03 \mathrm{ppm}$ ethylbenzene, and $0.06 \mathrm{ppm}$ xylene. Benzene in air was significantly correlated with unmetabolized benzene in blood $(r=0.69, p<0.001)$ and urine $(r=0.64$, $p<0.001)$, but not with urinary $t, t$-MA $\quad(r=0.27$, $p=0.20$ ). Toluene in air was highly correlated with the internal dose of toluene in both blood $(r=0.70$, $p<0.001)$ and urine $(r=0.73, p<0.001)$. Co-exposures were present; however, an interaction of metabolism was not likely at these low benzene and toluene exposures.

Conclusion Urinary benzene, but not $t, t$-MA, was a reliable biomarker for benzene at low exposure levels. Urinary toluene was a useful biomarker for toluene exposure. Xylene and ethylbenzene air levels were low. Dermal exposure assessment needs to be performed in future studies among these workers.

Keywords Benzene $\cdot$ Toluene $\cdot$ Xylene Ethylbenzene Biomonitoring $\cdot$ Petroleum workers $\cdot$ Crude oil

\section{Introduction}

The aromatic hydrocarbons benzene, toluene, ethylbenzene, and xylene (collectively labeled: BTEX) are simultaneously present in crude oil. While benzene (Group 1) (IARC 1987) and ethylbenzene (Group 2b) (IARC 2000) have been classified as carcinogens, the main concern for exposures to toluene and xylene are their effects on the 
central nervous system. Studies performed in the upstream petroleum industry have reported wide ranges of volatile organic hydrocarbon concentrations measured in air (Verma et al. 2000; Glass et al. 2000; Steinsvåg et al. 2007; Bråtveit et al. 2007; Runion 1988; Kirkeleit et al. 2006a), as well as increased risk of cancer types that has been associated with these hydrocarbons such as leukemia (Glass et al. 2003; Kirkeleit et al. 2008; Aas et al. 2009), multiple myeloma (Kirkeleit et al. 2008), malignant melanoma (Lewis et al. 2000; Sorahan et al. 2002; Gun et al. 2004, 2006; Christie et al. 1991; Wong and Raabe 2000), and kidney cancer (Gun et al. 2006).

Co-exposures to benzene and toluene have been shown to interact during their metabolism but the degree of interaction depends on the intensity of exposure. For example, in a study of factory workers exposed to either benzene alone (geometric mean (GM) $20 \mathrm{ppm}$ ), toluene alone (GM $38 \mathrm{ppm}$ ), or a combination of both (GM 6 and $12 \mathrm{ppm}$ for benzene and toluene, respectively), the urinary levels of phenol (a metabolite of benzene) and hippuric acid (a metabolite of toluene) were shown to be significantly lower among the co-exposed workers as compared with the levels in workers who were exposed to either benzene or toluene alone (Inoue et al. 1988). A recent study, exposing mice intermittently to low levels of benzene and toluene showed that toluene co-exposure doubled the genotoxic response (as determined by the erythrocyte micronucleus test) to benzene alone (Bird et al. 2010). However, no systematic review of the literature on coexposure of these hydrocarbons has been reported, possibly due to the multiple combinations of co-exposures and exposure intensities.

The main route of absorption for volatile aromatic hydrocarbons is by inhalation. However, percutaneous absorption has been estimated to $0.2-20 \%$ of the total amount absorbed depending on contact time for benzene (ACGIH 2001) and to 1-2\% for toluene (Brooke et al. 1998). Not only liquids, but also vapors may penetrate skin (Riihimaki and Pfaffli 1978). In workplace situations, wearing protective suits may even enhance dermal penetration of vapor (Jones et al. 2003). To estimate the internal dose from all routes of exposure, it is therefore advantageous to use biological monitoring (Lauwerys and Hoet 1993), which also considers the inter-individual variations in absorption as well as individual variation in metabolism, excretion, and bioavailability of the chemical agents. The internal benzene dose can be estimated by several biomarkers; the most important are unmetabolized benzene in blood and urine, and the metabolites trans,trans-muconic acid ( $t, t$-MA) and $S$-phenylmercapturic acid (SPMA) in urine (ACGIH 2001). However, the sensitivity and specificity of these markers have been questioned when exposures are at or below 1 ppm (ACGIH 2001). Biological monitoring of occupational exposures to toluene is based on validated urinary biomarkers, such as hippuric acid and $o$-creosol for toluene. New biomarkers such as toluene in urine and $S$-benzyl-mercaputuric acid (SBMA) for toluene have been suggested to improve sensitivity and specificity at low concentrations (ACGIH 2007; Lovreglio et al. 2010; Ducos et al. 2008). Currently, there is a discrepancy found in the literature regarding the usefulness of unmetabolized benzene and toluene as exposure biomarkers especially in work environments with low exposures.

We have reported that the benzene concentrations in upstream petroleum workers' blood and urine were highly correlated with benzene air concentrations (Kirkeleit et al. 2006b; Bråtveit et al. 2007). Adjusting for smoking did not materially change the results. We also found that the internal concentrations of benzene appeared higher than expected considering the measured individual benzene exposure in air (Kirkeleit et al. 2006b). This could either be due to co-exposure to other aromatic hydrocarbons, which may inhibit benzene metabolism (Boogaard and van Sittert 1994; Brondeau et al. 1992; Inoue et al. 1988), greater than average uptake due to physical exertion, or that especially benzene, which carries an ACGIH skin notation, may also enter the body via dermal absorption (ACGIH 2001; Adami et al. 2006; Carlsson 1982; Nomiyama and Nomiyama 1974). In order to reduce health risks in the upstream petroleum industry, there is a need for more knowledge about exposures to hydrocarbons simultaneously present in crude oil.

This study was part of a study of benzene concentrations in upstream petroleum workers' blood and urine (Kirkeleit et al. 2006b; Bråtveit et al. 2007) where exposure levels and quantitative relationships between benzene in air, blood, and urine for two groups of workers tank workers and process operators were presented in two separate papers (Kirkeleit et al. 2006a, b; Bråtveit et al. 2007). We present here, not previously published, toluene exposure levels in the working atmosphere and biological media as well as urinary $t, t$-MA concentrations. Using the pooled data set (Kirkeleit et al. 2006b; Bråtveit et al. 2007) to increase the statistical power, we explored the utility of $t, t$ MA as a biomarker of benzene exposure and the usefulness of unmetabolized benzene and toluene biomarkers in this worker population exposed to low levels of BTEX. Currently, no exposure measurements have been reported in the literature regarding exposures to xylene and ethyl benzene in offshore workers. Here, we present results of a small pilot study measuring air concentrations of these components.

We further investigated the possible effects of coexposures to petroleum-derived hydrocarbons using toluene and benzene biomarkers in multiple regression analysis including smoking as a covariate. 
Our objectives in this study were to:

1. Present air and biological concentrations of toluene and concentrations of urinary $t, t$-MA.

2. Evaluate air concentrations of ethylbenzene and xylene.

3. Explore the utility of $t, t-\mathrm{MA}$ as an exposure biomarker of benzene and the usefulness of unmetabolized toluene and benzene as biomarkers of toluene and benzene, respectively, in this worker population.

4. Assess co-exposures of benzene and toluene among petroleum workers exposed to crude oil.

\section{Methods}

\section{Study population}

The study population included 43 offshore petroleum production workers employed on the Norwegian continental shelf and have been described in detail elsewhere (Bråtveit et al. 2007; Kirkeleit et al. 2006b). Two exposed groups were identified: "tank workers" $(n=13)$ who worked in crude oil cargo tanks were recruited from a crude oil production vessel where they performed tank cleaning, tank inspection, scaffold construction, and welding to mend leaks; and "process operators" $(n=12)$ recruited from a fixed oil and gas installation where they ran the day-to-day operations in the processing area. All "controls" ( $n=9$ for each exposure group, giving a total of 18 controls) worked in the living quarters and were recruited from the same installations and shifts as the exposed workers. Three of the tank workers did not perform their scheduled tank cleaning tasks during the study, but rather performed tasks typical for the "process operators". For the purpose of this analysis, we therefore recoded these workers from being in the "tank worker" group to "process operator" group due to their similar exposures with this latter group. The final exposure groups comprised 10 tank workers, 15 process operators, and 18 controls.

The tank workers generally used a chemical resistant protective suit during cleaning the tank. Respirators equipped with organic vapor cartridges were made available to both process operators and tank workers; however, we did not record respirator use and change-out schedule, and thus cannot account for efficiency of protection in our analyses.

All participants signed an informed written consent and completed a self-administered questionnaire including a question on whether they were current smokers (yes/no) during the study period. The study protocol was approved by the Western Norway Regional Committee for Medical Research Ethics and the Data Inspectorate.

Personal air concentrations

The tank workers and process operators were monitored for personal exposure to BTEX during three consecutive 12-h work shifts using organic vapor passive dosimetry badges $\left(3 \mathrm{M} 3500^{\circledR}\right.$, St. Paul, MN, USA) as described in Kirkeleit et al. (2006b) and Bråtveit et al. (2007). The arithmetic mean sampling time for process operators $(n=44)$ and tank workers $(n=26)$ were 647 min (range 379-730) and 608 min (range 224-931), respectively. We did not measure the personal exposure to benzene for the control group. BTEX were desorbed in $\mathrm{CS}_{2}$ and analyzed quantitatively and qualitatively by GC/MS (NIOSH NMAM 2003). The level of detection was $0.001 \mathrm{ppm}$ for benzene and $0.01 \mathrm{ppm}$ for toluene, ethylbenzene, and xylene.

Collection of blood and urine samples

Urine $(n=81)$ and blood $(n=60)$ samples used for this analysis were collected as part of a biomonitoring study on benzene, which have been described in detail elsewhere (Kirkeleit et al. 2006b; Bråtveit et al. 2007). In short, preshift blood- and urine samples were collected in the morning before the tank workers entered the tank and for process operators in the morning at the heliport before departure to the offshore oil- and gas installation. Post-shift blood- and urine samples were collected immediately at the end of the 12-h shift on the third day of tank work for tank workers, and for process operators, immediately after work on the 13th day, when they were scheduled to return onshore. The postshift sample was collected on the third day of the monitoring of environmental concentrations of BTEX. Control subjects were monitored for markers of exposure in blood and urine, and the collection times for the controls were the same as for the respective exposed participants. Pre-shift blood- and urine samples were not collected from two process operators due to late enrollment into the study. As recommended by the laboratory, blood samples were collected by venipuncture into Venoject II $^{\circledR}$ tubes with heparin, while urine samples were collected in glass bottles $\left(\right.$ PYREX $\left.^{\circledR}\right)$ with polypropene stoppers. The samples for analysis of benzene, toluene, and $t, t$-MA were stored at $4{ }^{\circ} \mathrm{C}$ in vapor-tight vials until analysis (maximum 3 months).

Methods for analyzing benzene in blood and urine have been described previously (Kirkeleit et al. 2006b; Bråtveit et al. 2007) and were similar for the analysis of toluene. In short, the concentrations of benzene and toluene in blood were analyzed by a head-space sampler (Perkin Elmer Headspace sampler HS40, Wellesley, MA, USA) and a gas 
chromatograph (GC) (Perkin Elmer Autosystem) using photoionization detection according to the method described by Pekari et al. (1989, 1992). The samples with benzene or toluene levels at above $5 \mathrm{nmol} / \mathrm{l}$ were analyzed by multi-head space extraction (Ettre and Jones 1984). The level of quantification was $1 \mathrm{nmol} / \mathrm{l}$, while the "not detected level" was marked as half of the quantification limit $(0.5 \mathrm{nmol} / \mathrm{l})$.

Urinary benzene and toluene concentrations were analyzed using GC (Varian Saturn 3400 CX, Varian 8200 CX autosampler, Palo Alto, CA, USA) and a mass spectrometer (MS) (Varian Saturn 2000). Ions $50^{+}, 77^{+}$, and $78^{+}$ were selected for quantifying benzene. The quantifications were based on an internal standard method (chlorobenzene). The level of quantification was $1 \mathrm{nmol} / \mathrm{l}$, while the "not detected level" was marked as half of the quantification limit $(0.5 \mathrm{nmol} / \mathrm{l})$.

Muconic acid was separated from the urine sample by solid phase extraction in an ion exchange column. The extracted sample was then analyzed by an LC-UV method. The sample $(25 \mu \mathrm{l})$ was injected to Agilent 1100 HPLC system (autosampler, pump unit, degasser, UV detector). The column used was LiChrosorb RP-8 $(200 \times 4.6 \mathrm{~mm}$, particle size $5 \mu \mathrm{m}$ ), the eluent consisted of $18-25 \%$ methanol and $0.1 \%$ phosphoric acid (flow $1.0 \mathrm{ml} / \mathrm{min}$ ), the detector wavelength was $259 \mathrm{~nm}$, and the retention time for $t, t$-MA was about $7 \mathrm{~min}$. The level of quantification was $0.5 \mu \mathrm{mol} / 1$.

\section{Statistical methods}

Distributions of all variables were tested for normality using the Shapiro-Wilk test. All variables were skewed and were transformed to their natural logarithm (ln) before further analysis. All measurements below the limit of detection (LOD) were replaced with values equal to the LOD/2 (Hornung and Reed 1990). To account for differences in urine density between study participants, $t, t$-MA was corrected with specific gravity. The specific gravity should be between 1.010 and 1.030. If specific gravity was below or above these values, 1.010 and 1.030, respectively, a correction of 1.024 was used.

For analysis of associations between exposure in the work environment and concentration of benzene, toluene, and $t, t$-MA in biological media, the exposure concentration measured on the day of sampling the post-shift sample (third day) was chosen. Correlation studies were carried out using Sigma plot software on values that had been transformed to their natural logarithm. Correlations between variables were assessed by Pearson's $r$ coefficient.

Mixed models analysis of covariance (ANCOVA) was performed using the PROC MIXED procedure in SAS version 9.1 (SAS Institute Inc. 2000-2003) to account for repeated urine measurements collected for each study participant. We used a backward elimination stepwise regression analysis to evaluate possible co-exposures. Covariates and interaction terms that were not statistically significant $(p$ value $>0.05)$ were removed in a stepwise fashion, beginning with the most complex interaction term. Both post-shift urinary benzene (models A-C) and postshift blood benzene (models D-F) were tested in separate models (Table 3). Covariates included in all the models were: job (process operator, tank worker, and control subjects), age, pre-shift blood/urine benzene values, and interaction terms. Smoking, a known source of benzene exposure, was included in all the models. To assess how random variations and other biomarkers of exposures may influence the dependent variable (blood or urinary benzene concentrations), a three-tiered hierarchical approach was used:

I. The simplest model included the following covariates: job (process operator, tank worker, and control subjects), age, pre-shift blood/urine benzene values, and interaction terms; not included were other biomarkers of benzene (Table 3, model A and D);

II. The random variation model included the covariates as in the previous model and other biomarkers of benzene exposures ( $t, t$-MA and blood benzene concentrations for the urinary post-shift benzene model and vice versa) (Table 3, model $\mathrm{B}$ and $\mathrm{E}$ );

III. The co-exposure model included the covariates as in the previous model and biomarkers of co-exposure to toluene (Table 3, model $\mathrm{C}$ and $\mathrm{F}$ ).

To test the possibility of metabolic interaction between benzene and toluene due to co-exposure, we compared the regression lines (slopes) of our present observation with the slopes reported in a study with higher exposure levels; the study of Waidyanatha et al. (2001) determining urinary benzene in workers with a median daily exposure of $31 \mathrm{ppm}$. We regressed urinary benzene post-shift $(n=25)$ on benzene air concentrations averaged over 3 days of sampling. Our controls were not included because we did not collect benzene air concentrations for this group.

\section{Results}

Study population

Most of the workers were men: controls $(62.5 \%)$, process operators $(66.7 \%)$, and tank workers $(100 \%)$. More than $2 / 3$ of all workers were non-smokers (controls: $29 \%$ smokers, tank workers: $31 \%$ smokers, and process operators: $25 \%$ smokers). Tank workers (median age 30.8 years; range 27.0-55.0) were somewhat younger than both 
controls (median age 45 years; range 29.0-60.0) and process operators (median age 44.5 years, range 22.0-59.0).

\section{Environmental exposure to BTEX}

Descriptive statistics of BTEX by exposure group (controls, process operators, and tank workers) are presented in Table 1. The BTEX air concentrations differed between exposure groups and were significantly different between process operators and tank workers (mean exposure over the 3-day study period; benzene $p=0.001$, toluene $p=$ 0.001 , ethylbenzene $p=0.002$, and xylene $p<0,001)$. The benzene air concentration was highly correlated with the other hydrocarbons; toluene $(r=0.89, p<0.001)$, ethylbenzene $(r=0.76, p<0.001)$, and xylene $(r=0.90$, $p<0.001)$.

Biomarkers of benzene in blood and urine

Descriptive statistics of biomarkers of exposure to benzene by exposure group (controls, process operators, and tank workers) and pooled data for the exposed workers are presented in Table 2. The correlation between benzene concentration in air third day of study and biological media post-shift among exposed workers was high both in blood ( $r=0.69, p=0.0003, n=22)$ and urine $(r=0.64$, $p=0.0005, n=25$ ). The correlation between benzene in air and urinary $t, t$-MA post-shift was low and not significant $(r=0.27, p=0.20, n=25)$. Benzene concentration in the air on the third day of study only explained $7 \%$ of the variation in urinary $t, t$-MA post-shift, while the corresponding percentage for benzene in blood and urine were 48 and 41\%, respectively. Adjusting for smoking in multiple regression analyses did not materially change the reported correlations. Correlations between post-shift benzene exposure biomarkers by exposure group and for all offshore workers combined are shown in Fig. 1. The strongest correlation was between benzene in blood and urine, and the weakest for the correlation between blood benzene and $t, t$-MA.

Assessment of urinary toluene as an exposure biomarker for low toluene concentrations

Descriptive statistics of biomarkers of exposure to toluene by exposure group (controls, process operators, and tank workers) and pooled data for the exposed workers are presented in Table 2. Toluene in air showed a good correlation with the internal dose of toluene in blood $(r=0.70$, $p<0.001, n=22)$ and urine $(r=0.73, \quad p<0.001$, $n=25$ ) post-shift among the exposed workers, explaining 49 and $54 \%$ of the variation in post-shift blood and urinary

Table 1 Descriptive statistics for BTEX air concentrations by exposure group

\begin{tabular}{|c|c|c|c|c|c|c|c|c|c|c|c|c|c|c|c|}
\hline \multirow[t]{2}{*}{ Variable } & \multicolumn{5}{|c|}{ Process operators $(n=15)$} & \multicolumn{5}{|c|}{ Tank workers $(n=10)$} & \multicolumn{5}{|c|}{ Exposed workers $(n=25)$} \\
\hline & $n$ & $\%>\mathrm{LOD}$ & $\mathrm{AM}$ & GM & GSD & $n$ & $\%>\mathrm{LOD}$ & $\mathrm{AM}$ & GM & GSD & $n$ & $\%>\mathrm{LOD}$ & $\mathrm{AM}$ & GM & GSD \\
\hline \multicolumn{16}{|c|}{ Benzene (ppm) } \\
\hline Day 1 & 15 & 87 & 0.13 & 0.01 & 11.4 & 8 & 100 & 0.30 & 0.22 & 2.44 & 23 & 91 & 0.19 & 0.04 & 11.1 \\
\hline Day 2 & 14 & 79 & 0.04 & 0.005 & 7.66 & 8 & 100 & 0.24 & 0.16 & 2.84 & 22 & 86 & 0.12 & 0.02 & 10.8 \\
\hline Day 3 & 15 & 87 & 0.01 & 0.006 & 3.96 & 10 & 100 & 0.18 & 0.11 & 3.29 & 25 & 92 & 0.08 & 0.02 & 6.85 \\
\hline All & 44 & 84 & 0.06 & 0.01 & 7.39 & 26 & 100 & 0.23 & 0.15 & 2.89 & 70 & 90 & 0.13 & 0.02 & 9.26 \\
\hline \multicolumn{16}{|c|}{ Toluene (ppm) } \\
\hline Day 1 & 15 & 80 & 0.19 & 0.04 & 7.38 & 8 & 100 & 1.61 & 0.60 & 3.79 & 23 & 87 & 0.68 & 0.11 & 8.93 \\
\hline Day 2 & 14 & 71 & 0.06 & 0.012 & 6.07 & 8 & 100 & 0.36 & 0.26 & 2.49 & 22 & 82 & 0.17 & 0.04 & 7.71 \\
\hline Day 3 & 15 & 47 & 0.02 & 0.01 & 3.41 & 10 & 100 & 0.27 & 0.17 & 3.06 & 25 & 68 & 0.12 & 0.03 & 6.73 \\
\hline All & 44 & 66 & 0.09 & 0.02 & 6.02 & 26 & 100 & 0.71 & 0.29 & 3.34 & 70 & 79 & 0.32 & 0.05 & 8.09 \\
\hline \multicolumn{16}{|c|}{ Ethylbenzene (ppm) } \\
\hline Day 1 & 15 & 93 & 0.07 & 0.04 & 3.07 & 8 & 100 & 0.18 & 0.13 & 2.43 & 23 & 96 & 0.11 & 0.06 & 3.30 \\
\hline Day 2 & 14 & 79 & 0.03 & 0.02 & 2.29 & 8 & 100 & 0.13 & 0.08 & 2.66 & 22 & 86 & 0.06 & 0.03 & 3.08 \\
\hline Day 3 & 15 & 87 & 0.01 & 0.01 & 1.65 & 10 & 100 & 0.09 & 0.06 & 2.72 & 25 & 92 & 0.04 & 0.02 & 2.92 \\
\hline All & 44 & 86 & 0.04 & 0.02 & 2.63 & 26 & 100 & 0.13 & 0.08 & 2.68 & 70 & 91 & 0.07 & 0.03 & 3.26 \\
\hline \multicolumn{16}{|c|}{ Xylene, all isomers (ppm) } \\
\hline Day 1 & 15 & 33 & 0.32 & 0.02 & 12.1 & 8 & 100 & 1.02 & 0.80 & 2.13 & 23 & 57 & 0.56 & 0.08 & 14.5 \\
\hline Day 2 & 14 & 43 & 0.06 & 0.02 & 4.78 & 8 & 100 & 0.73 & 0.50 & 2.55 & 22 & 64 & 0.30 & 0.07 & 7.94 \\
\hline Day 3 & 15 & 27 & 0.02 & 0.01 & 2.78 & 10 & 100 & 0.46 & 0.30 & 3.05 & 25 & 56 & 0.19 & 0.04 & 7.71 \\
\hline All & 44 & 34 & 0.13 & 0.02 & 6.12 & 26 & 100 & 0.72 & 0.47 & 2.75 & 70 & 67 & 0.35 & 0.06 & 9.67 \\
\hline
\end{tabular}




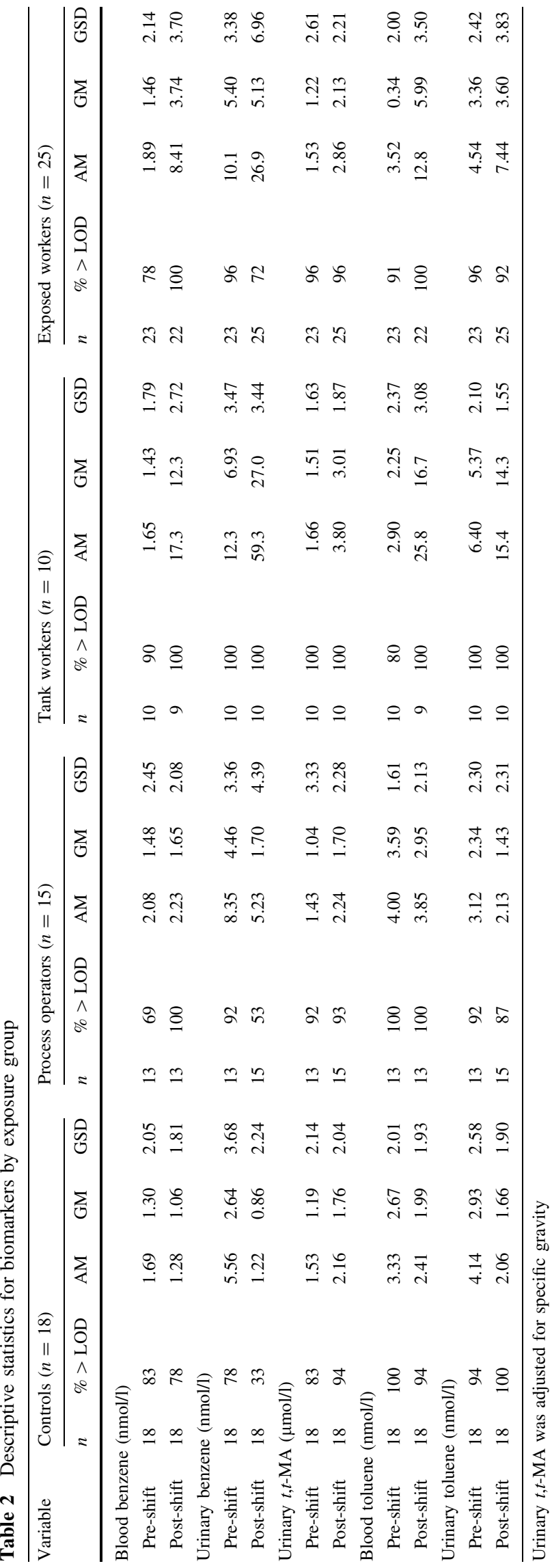

toluene, respectively. The correlation between toluene in blood and urine post-shift was 0.66 ( $p<0.005$ ) (Fig. 1).

Assessment of possible co-exposures

Results from a set of ANOVA models for post-shift urinary benzene (models A-C) and post-shift blood benzene (models D-F) are given in Table 3. Both post-shift benzene biomarkers showed an exposure difference between the three exposure groups (job) in the simplest models (models $A$ and D). The final model for urinary benzene post-shift included job ( $p$ value $<0.0001$ ), pre-shift urinary benzene ( $p$ value $=0.0005)$, and the interaction term job*pre-shift urinary benzene ( $p$ value $=0.01$ ), while the final model for blood benzene post-shift included job ( $p$ value $<0.0001)$, pre-shift blood benzene ( $p$ value $=0.001)$, and two interaction terms: job*smoking ( $p$ value $=0.01$ ), and job*preshift blood benzene ( $p$ value $=0.01$ ). The second approach included $t, t$-MA as a covariate, and this model also showed a significant difference between jobs; however, it changed the final models. Urinary benzene post-shift model (B) included job $(p$ value $=0.009)$, pre-shift urinary benzene $(p$ value $=$ 0.0002 ), post-shift blood benzene ( $p$ value $<0.0001$ ), postshift $t, t$-MA ( $p$ value $=0.001)$, and an interaction term job*pre-shift urinary benzene levels $(p$ value $=0.001)$; and the blood benzene post-shift model (E) included job ( $p$ value $<0.0001)$, pre-shift blood benzene ( $p$ value $=$ $0.001)$, pre-shift $(p$ value $=0.002$ ) and post-shift urinary benzene ( $p$ value $=0.002)$, and two interaction terms (job*smoking $(p$ value $=0.004)$ and job*pre-shift blood benzene $(p$ value $=0.003)$ ). Including all biomarkers for benzene exposures (un-metabolized and metabolized) and co-exposure biomarkers (models $\mathrm{C}$ and $\mathrm{F}$ ) did not lead to a significant difference between jobs in the post-shift urinary benzene model $(\mathrm{C})$, but did show a difference in the post-shift blood benzene model $(\mathrm{F})$. The final model $(\mathrm{F})$ included job $(p$ value $=0.001)$, pre-shift blood benzene $(p$ value $=0.01)$, pre-shift urinary $t, t$-MA ( $p$ value $=0.009)$, pre-shift urinary toluene $(p$ value $=0.005)$, and post-shift blood toluene ( $p$ value $<0.0001$ ). Smoking was not a significant covariate in the post-shift urinary benzene models, while smoking's interaction with job was significant in two post-shift blood benzene models ( $\mathrm{D}$ and $\mathrm{E}$ ).

The relationship between urinary benzene and benzene air concentrations was strong with a slope of 0.61 , which compares favorably with Waidyanatha et al.'s (2001) slope estimate of 0.71 .

\section{Discussion}

BTEX air concentrations were low compared to recommended occupational limits, but were significantly higher 
Fig. 1 Correlations between biomarkers of exposure (natural $\log$ transformed) for all offshore workers; process operators and their controls (open circle) and tank workers and their controls (black inverted triangle)
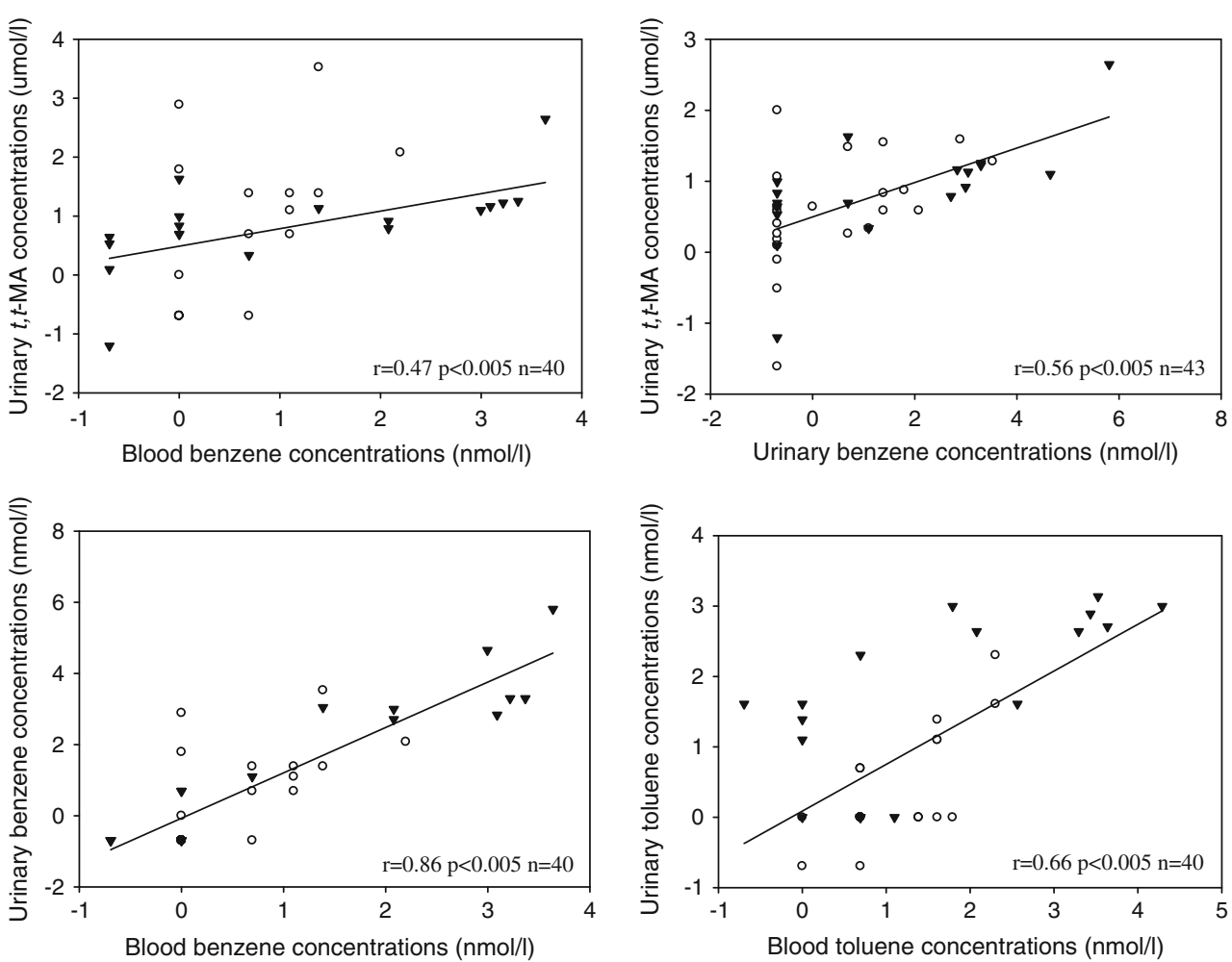

in tank workers than in process operators. Urinary benzene, but not urinary $t, t$-MA, was a reliable biomarker for benzene exposure. Urinary toluene was a useful biomarker for toluene exposure at low exposure levels. Few measurements were below the LOD, except for post-shift urinary benzene levels for controls (Table 2).

Occupational exposure limit values for $8 \mathrm{~h}$ of work for these compounds have been set by the Scientific Committee on Occupational Exposure Limit (SCOEL) in the European Union (EU) and the American Conference of Governmental Industrial Hygienist (ACGIH) and are as follows: benzene: $0.5 \mathrm{ppm}$ (ACGIH) and $1 \mathrm{ppm}$ (SCOEL), toluene: $20 \mathrm{ppm}(\mathrm{ACGIH})$ and $50 \mathrm{ppm}$ (SCOEL), xylene: 100 ppm (ACGIH) and 50 ppm (SCOEL), and ethylbenzene: $100 \mathrm{ppm}$ (ACGIH and SCOEL). Even though our BTEX air concentrations were low compared to recommended occupational limits, they did differ between exposure groups and were significantly different between process operators and tank workers. The reported difference between the BTEX concentrations in process operators and tank workers was likely due to the nature of their tasks; tank workers were directly exposed to crude oil residues in the tank (Kirkeleit et al. 2006b), while process operators the majority of their time worked around closed systems (Bråtveit et al. 2007).

Published data on exposure to aromatic hydrocarbons other than benzene in the petroleum industry are scarce, probably due to more focus on benzene that is a known human carcinogen with an exposure limit that is much lower than the respective limit values for the other aromatic hydrocarbons. Most of the studies on the exposure to these hydrocarbons relevant for the petroleum industry have been done on service station attendants exposed to gasoline, where the reported mean exposure range between 0.14 and $1.17 \mathrm{mg} / \mathrm{m}^{3}$ for toluene (Rekhadevi et al. 2010; Lovreglio et al. 2010; Keretetse et al. 2008; Periago and Prado 2005) and between 0.22 and $0.96 \mathrm{mg} / \mathrm{m}^{3}$ for xylene (Rekhadevi et al. 2010; Keretetse et al. 2008; Periago and Prado 2005). Workers maintaining, repairing, and inspecting gasoline pumps had a time-weighted average exposure level of toluene, ethylbenzene, and xylene of $2.2 \mathrm{mg} / \mathrm{m}^{3}\left(0.27-4.3 \mathrm{mg} / \mathrm{m}^{3}\right), 0.26 \mathrm{mg} / \mathrm{m}^{3}(0.03-0.75 \mathrm{mg} /$ $\left.\mathrm{m}^{3}\right)$ and $1.1 \mathrm{mg} / \mathrm{m}^{3}\left(0.11-2.47 \mathrm{mg} / \mathrm{m}^{3}\right)$, respectively (Vainiotalo et al. 2006). Hence, the exposures to toluene, ethylbenzene, and xylene found among petroleum workers in the present study were well below occupational exposure limits, but also lower than what has been reported for other occupational settings relevant for the petroleum industry. The level of BTEX measured in air was highly correlated with each other, which is in agreement with co-exposure of agents from the petroleum stream.

Occupational exposure studies often involve observations below the analytical LOD, resulting in left-censored lognormally distributed data. Substituting the values below LOD with LOD/2 may introduce bias. The amount of bias may be highly variable (Ganser and Hewett 2010). 
Table 3 Multiple regression models including several biomarkers for the same exposures and co-exposure biomarkers

\begin{tabular}{|c|c|c|c|c|c|c|c|c|c|c|c|c|}
\hline \multirow[t]{3}{*}{ Model } & \multicolumn{6}{|c|}{ Urinary benzene post-shift models } & \multicolumn{6}{|c|}{ Blood benzene post-shift models } \\
\hline & \multicolumn{2}{|l|}{ A } & \multicolumn{2}{|l|}{$\mathrm{B}$} & \multicolumn{2}{|l|}{$\mathrm{C}$} & \multicolumn{2}{|l|}{$\mathrm{D}$} & \multicolumn{2}{|l|}{$\mathrm{E}$} & \multicolumn{2}{|l|}{$\mathrm{F}$} \\
\hline & Incl. & Sign* & Incl. & Sign* & Incl. & Sign* & Incl. & Sign* & Incl. & Sign* & Incl. & Sign* \\
\hline \multicolumn{13}{|l|}{ Independent variables } \\
\hline Job & $\mathrm{y}$ & $*$ & $\mathrm{y}$ & $*$ & $\mathrm{y}$ & ns & $\mathrm{y}$ & $*$ & $\mathrm{y}$ & $*$ & $\mathrm{y}$ & $*$ \\
\hline Smoking & $\mathrm{y}$ & ns & $\mathrm{y}$ & ns & $\mathrm{y}$ & ns & $\mathrm{y}$ & ns & $\mathrm{y}$ & ns & $\mathrm{y}$ & ns \\
\hline Age & $\mathrm{y}$ & ns & $\mathrm{y}$ & ns & $\mathrm{y}$ & ns & $\mathrm{y}$ & ns & $\mathrm{y}$ & ns & $\mathrm{y}$ & ns \\
\hline Pre-shift urinary benzene & $\mathrm{y}$ & $*$ & $\mathrm{y}$ & $*$ & $\mathrm{y}$ & $*$ & $\mathrm{n}$ & - & $\mathrm{y}$ & $*$ & $\mathrm{y}$ & ns \\
\hline Pre-shift blood benzene & $\mathrm{n}$ & - & $\mathrm{y}$ & ns & $\mathrm{y}$ & ns & $\mathrm{y}$ & * & $\mathrm{y}$ & $*$ & $\mathrm{y}$ & $*$ \\
\hline Post-shift urinary benzene & $\mathrm{dv}$ & - & $\mathrm{dv}$ & - & $\mathrm{dv}$ & - & $\mathrm{y}$ & ns & $\mathrm{y}$ & $*$ & $\mathrm{y}$ & ns \\
\hline Post-shift blood benzene & $\mathrm{y}$ & ns & $\mathrm{y}$ & $*$ & $\mathrm{y}$ & ns & $\mathrm{dv}$ & - & $\mathrm{dv}$ & - & $\mathrm{dv}$ & - \\
\hline \multicolumn{13}{|l|}{ Interactions } \\
\hline Job*Smoking & $\mathrm{y}$ & ns & $\mathrm{y}$ & ns & $\mathrm{y}$ & ns & $\mathrm{y}$ & $*$ & $\mathrm{y}$ & $*$ & $\mathrm{y}$ & ns \\
\hline Job*Age & $\mathrm{y}$ & ns & $\mathrm{y}$ & ns & $\mathrm{y}$ & ns & $\mathrm{y}$ & ns & $\mathrm{y}$ & ns & $\mathrm{y}$ & ns \\
\hline Job*Pre-shift blood benzene & $\mathrm{n}$ & - & $\mathrm{n}$ & - & $\mathrm{n}$ & - & $\mathrm{y}$ & $*$ & $\mathrm{y}$ & $*$ & $\mathrm{y}$ & ns \\
\hline Job*Pre-shift urinary benzene & $\mathrm{y}$ & $*$ & $\mathrm{y}$ & $*$ & $\mathrm{y}$ & ns & $\mathrm{n}$ & - & $\mathrm{n}$ & - & $\mathrm{n}$ & - \\
\hline Smoking*Age & $\mathrm{y}$ & ns & $\mathrm{y}$ & ns & $\mathrm{y}$ & ns & $\mathrm{y}$ & ns & $\mathrm{y}$ & ns & $\mathrm{y}$ & ns \\
\hline Smoking*Pre-shift blood benzene & $\mathrm{n}$ & - & $\mathrm{n}$ & - & $\mathrm{n}$ & - & $\mathrm{y}$ & ns & $\mathrm{y}$ & ns & $\mathrm{y}$ & ns \\
\hline Smoking*Pre-shift urinary benzene & $\mathrm{y}$ & ns & $\mathrm{y}$ & ns & $\mathrm{y}$ & ns & $\mathrm{n}$ & - & $\mathrm{n}$ & - & $\mathrm{n}$ & - \\
\hline Age*Pre-shift blood benzene & $\mathrm{n}$ & - & $\mathrm{n}$ & - & $\mathrm{n}$ & - & $\mathrm{y}$ & ns & $\mathrm{y}$ & ns & $\mathrm{y}$ & ns \\
\hline Age*Pre-shift urinary benzene & $\mathrm{y}$ & ns & $\mathrm{y}$ & ns & $\mathrm{y}$ & ns & $\mathrm{n}$ & - & $\mathrm{n}$ & - & $\mathrm{n}$ & - \\
\hline Job*Age*Smoking & $\mathrm{y}$ & ns & $\mathrm{y}$ & ns & $\mathrm{y}$ & ns & $\mathrm{y}$ & ns & $\mathrm{y}$ & ns & $\mathrm{y}$ & ns \\
\hline Metabolites included & $\mathrm{n}$ & - & $\mathrm{y}$ & - & $\mathrm{y}$ & - & $\mathrm{n}$ & - & $\mathrm{y}$ & - & $\mathrm{y}$ & - \\
\hline Pre-shift urinary $t, t$-MA & - & - & $\mathrm{y}$ & ns & $\mathrm{y}$ & ns & - & - & $\mathrm{y}$ & ns & $\mathrm{y}$ & $*$ \\
\hline Post-shift urinary $t, t$-MA & - & - & $\mathrm{y}$ & $*$ & $\mathrm{y}$ & $*$ & - & - & $\mathrm{y}$ & ns & $\mathrm{y}$ & ns \\
\hline Co-exposure biomarkers included & $\mathrm{n}$ & - & $\mathrm{n}$ & - & $\mathrm{y}$ & - & $\mathrm{n}$ & & $\mathrm{n}$ & & $\mathrm{y}$ & \\
\hline Pre-shift urinary toluene & - & - & - & - & $\mathrm{y}$ & ns & - & - & - & - & $\mathrm{y}$ & $*$ \\
\hline Pre-shift blood toluene & - & - & - & - & $\mathrm{y}$ & ns & - & - & - & - & $\mathrm{y}$ & ns \\
\hline Post-shift urinary toluene & - & - & - & - & $\mathrm{y}$ & $*$ & - & - & - & - & $\mathrm{y}$ & ns \\
\hline Post-shift blood toluene & - & - & - & - & $\mathrm{y}$ & $*$ & - & - & - & - & $\mathrm{y}$ & $*$ \\
\hline
\end{tabular}

Job (tank worker, process operator, controls), smoking (current, never). Incl independent variable included in the model, Sign* significant, $y$ yes, $n$ no, $d v$ dependent variable, $n s$ not significant

* Significant at $p<0.05$

Maximum likelihood estimates (MLE) have emerged as the best approach in these cases (Jin et al. 2011); however, when the dataset deviate substantially from a simple lognormal distribution as it did in the benzene exposure dataset of the Australian petroleum industry, the researchers decided that the LOD/2 method was most suitable (Glass and Gray 2001).

We have previously reported that the environmental benzene exposure was highly and significantly correlated with the post-shift concentration of both benzene in blood $(r=0.87)$ and urine $(r=0.90)$ for the tank workers (Kirkeleit et al. 2006b) and that these benzene measures only correlated in the group of process operators when we adjusted for being a current smoker (Bråtveit et al. 2007). Pooling the two data sets in the present study gave a somewhat weaker, but still strong, relationship between the benzene in air in blood $(r=0.69)$ and urine $(r=0.64)$. Correlation coefficients between benzene concentration in air and benzene in urine post-shift in other studies have been reported to be 0.38-0.98 (Lovreglio et al. 2010; Fustinoni et al. 2005; Hakkola and Saarinen 2000).

In contrast to the strong relationship between benzene in air and the internal dose of parent benzene in blood and urine, urinary $t, t$-MA was not correlated with benzene in air. Numerous studies in the petroleum- or petrochemical industries have reported that $t, t-\mathrm{MA}$ is not a reliable biomarker of benzene at exposure levels below $0.1 \mathrm{ppm}$ (Hoet et al. 2009; Carrieri et al. 2010). Workers exposed to benzene in the same range as the workers in the present study showed an even lower correlation between environmental 
benzene and urinary $t, t$-MA (Fustinoni et al. 2005). One possible explanation for the poor correlation between environmental benzene in air and $t, t-\mathrm{MA}$ in urine is that $t, t$ MA is also a metabolite of sorbic acid commonly used as a food additive (Hoet et al. 2009; Negri et al. 2005). We did not have any information on the use of sorbic acid in the food served to the workers. Also, although at a higher exposure level than in the present study, co-exposure to toluene in rats has been shown to lower $t, t$-MA exposure in a concentration-dependent manner (Brondeau et al. 1992).

Biomarker correlations were strong between urinary and blood benzene as has been shown in other studies (Hoet et al. 2009). The issue regarding the suitability of $t, t$-MA as a biomarker to monitor low exposure to benzene was apparent for blood benzene correlations with t,t-MA (Fig. 1). The correlation was weak and non-significant for low exposed process operators while for tank workers the correlation was significant, albeit not as good as between benzene in blood and urine. A lower correlation between $t, t$ MA and urinary benzene was also seen in process operators compared to tank workers. For toluene, the correlations between the biomarkers did not differ between exposure groups, showing that both toluene in blood and urine were reliable biomarkers for low toluene exposures. This has also been demonstrated by others (Kawai et al. 2008).

Smoking was only significant as an interaction term in the post-shift blood benzene model, but not in the urinary benzene models. This could be interpreted as the blood benzene biomarker being more sensitive to smoking than the urinary benzene biomarker at low benzene exposures. Urinary $t, t$-MA was a significant covariate in the urinary benzene post-shift model, but not in the blood benzene post-shift model. This might be explained by the physiological factors of urinary excretion; they will be collected in the bladder and excreted when the bladder is emptied, or because the half-life of blood benzene is shorter than in urine. $t, t$-MA might not be as sensitive a biomarker as blood benzene, hence not a significant covariate in this model (E). Post-shift blood benzene was a significant covariate for urinary benzene post-shift and vice versa, showing similar sensitivity at low benzene exposures (model B and E). Co-exposures are often accounted in upstream petroleum workers, and toluene may alter the metabolism of benzene (Bird et al. 2010; Inoue et al. 1988). Our models including co-exposure biomarkers for toluene (model $\mathrm{C}$ and $\mathrm{F}$ ) resulted in a non-significant urinary benzene model; hence, no difference between jobs could be detected, while post-shift blood benzene could still differentiate between types of jobs. This could indicate that blood benzene was more sensitive at low exposure than benzene in urine. Urinary toluene (both post- and preshift), not blood toluene, were significant covariates in this model. This could indicate a co-exposure result, meaning that there may be an interaction during metabolism. However, this must be interpreted with extreme caution for several reasons: (1) the source for benzene and toluene was the same (crude oil), thus the significance in the model could just be an indication of the same source, not an interaction in metabolism; (2) the toluene and benzene concentrations were treated as independent covariates in the model; however, this might not be correct as these biomarkers were correlated; (3) Could be due to random variation, which would be more pronounced since our concentrations are very low and from having few measurements (low statistical power). This is also supported by the similarity in slopes between workers only exposed to benzene (Waidyanatha et al. 2001) and our workers. This indicates that a metabolic interaction between benzene and toluene due to co-exposures is not likely.

Our results confirm that unmetabolized benzene in urine is a good biomarker for benzene exposure and can be used in biological monitoring of benzene at exposure levels below $1 \mathrm{ppm}$. Our results give further support to the argument for not using $t, t$-MA as an internal dose biomarker for benzene exposures at these low air concentration levels. A limitation with our study is that we did not evaluate other exposure biomarkers for benzene such as urinary $S$-phenylmercapturic acid and for toluene such as hippuric acid, $o$-creosol, and $S$-benzyl-mercaputuric acid. We were not able to include gender as a covariate in our analysis because the tank workers were all men. Excluding the tank workers from the multiple regression analysis and including only controls and low exposed process operators would not give a representative picture of possible gender differences.

\section{Conclusions}

Urinary benzene, not $t, t$-MA, should be used as a biomarker of benzene in the petroleum industry. Urinary toluene was a useful biomarker for toluene exposure. Our study shows that urine sampling is an efficient and very reliable way of assessing exposure to benzene and toluene in petroleum workers with low exposure and co-exposures to a range of petroleum-derived hydrocarbons. A better understanding of the work performed in upstream petroleum industry including dermal exposures, co-exposures, and use of personal protective equipment may lead to better exposure assessments in epidemiological studies and consequently our understanding of the increased risk of some cancer types reported among workers in this industry.

Acknowledgments This research study was supported by the Research Council of Norway under the PETROMAKS programme. Pertra AS and Norsk Hydro AS, the operators of the oil field during the study period financed the laboratory analysis for BTEX. We thank the management, employees, contract workers, and catering personnel 
on the production vessel Petrojarl Varg and Oseberg Field Center for their hospitality, cooperation, and flexibility throughout the study.

Conflict of interest The authors declare that they have no conflict of interest.

\section{References}

Aas GB, Aagnes B, Strand LA, Grimsrud TK (2009) Suggested excess of occupational cancers in Norwegian offshore workers: preliminary results from the Cancer Registry Offshore Cohort. Scand J Work Environ Health 35:397-399

Adami G, Larese F, Venier M, Barbieri P, Lo Coco F, Reisenhofer E (2006) Penetration of benzene, toluene and xylenes contained in gasolines through human abdominal skin in vitro. Toxicol In Vitro 20:1321-1330

American Conference of Governmental Industrial Hygienists (ACGIH) (2001) Documentation of the TLVs ${ }^{\circledR}$ and BEIs ${ }^{\circledR}, 2001$. Biological exposure index (BEI): for Benzene. ACGIH, Cincinnati

American Conference of Governmental Industrial Hygienists (ACGIH) (2007) Documentation of the TLVs ${ }^{\circledR}$ and BEIs ${ }^{\circledR}, 2007$. Biological exposure index (BEI): ethylbenzene, hexane, toluene and xylenes. ACGIH, Cincinnati

Bird MG, Wetmore BA, Letinski DJ, Nicolich M, Chen M, Schnatter AR, Whitman FT (2010) Influence of toluene co-exposure on the metabolism and genotoxicity of benzene in mice using continuous and intermittent exposures. Chem Biol Interact 184:233-239

Boogaard P, van Sittert N (1994) Exposure to polycyclic aromatic hydrocarbons in petrochemical industries by measurement of urinary 1-hydroxypyrene. Occup Environ Med 51:250-258

Bråtveit M, Kirkeleit J, Hollund BE, Moen BE (2007) Biological monitoring of benzene exposure for process operators during ordinary activity in the upstream petroleum industry. Ann Occup Hyg 51:487-494

Brondeau MT, Ducos P, Gaudin R, Morel G, Bonnet P, de Ceaurriz J (1992) Evaluation of the interaction of benzene and toluene on the urinary excretion of $t, t$-muconic acid in rats. Toxicol Lett 61:311-316

Brooke I, Cocker J, Delic J-L, Payne M, Jones K, Gregg NC, Dyne D (1998) Dermal uptake of solvent from the vapour phase: an experimental study in humans. Ann Occup Hyg 42:531-540

Carlsson A (1982) Exposure to toluene: uptake, distribution and elimination in man. Scand J Work Environ Health 8:43-55

Carrieri M, Tranfo G, Pigini D, Paci E, Salamon F, Scapellato ML, Fracasso ME, Manno M, Bartolucci GB (2010) Correlation between environmental and biological monitoring of exposure to benzene in petrochemical industry operators. Toxicol Lett 192:17-21

Christie D, Robinson K, Gordon I, Bisby J (1991) A prospective study in the Australian petroleum industry. II. Incidence of cancer. Br J Ind Med 48:511-514

Ducos P, Berode M, Francin JM, Arnoux C, Lefèvre C (2008) Biological monitoring of exposure to solvents using the chemical itself in urine: application to toluene. Int Arch Occup Environ Health 81:273-284

Ettre LS, Jones E (1984) Quantitative analysis with headspace gas chromatography using multiple headspace extraction. Chromatogr Newslett 12:1-3

Fustinoni S, Buratti M, Campo L, Colombi A, Consonni D, Pesatori AC, Bonzini M, Farmer P, Garte S, Valerio F, Merlo DF, Bertazzi PA (2005) Urinary $t, t$-muconic acid, $S$-phenylmercapturic acid and benzene as biomarkers of low benzene exposure. Chem Biol Interact 153-154:253-256
Ganser GH, Hewett P (2010) An accurate substitution method for analyzing censored data. J Occup Environ Hyg 7:233-244

Glass DC, Gray CN (2001) Estimating mean exposures from censored data: exposure to benzene in the Australian petroleum industry. Ann Occup Hyg 45:275-282

Glass DC, Adams GG, Manuell RW, Bisby JA (2000) Retrospective exposure assessment for benzene in the Australian petroleum industry. Ann Occup Hyg 44:301-320

Glass DC, Gray CN, Jolley DJ, Gibbons C, Sim MR, Fritschi L, Adams GG, Bisby JA, Manuell R (2003) Leukemia risk associated with low-level benzene exposure. Epidemiol 14: 569-577

Gun RT, Pratt NL, Griffith EC, Adams GG, Bisby JA, Robinson KL (2004) Update of a prospective study of mortality and cancer incidence in the Australian petroleum industry. Occup Environ Med 61:150-156

Gun RT, Pratt N, Ryan P, Roder D (2006) Update of mortality and cancer incidence in the Australian petroleum industry cohort. Occup Environ Med 63:476-481

Hakkola MA, Saarinen LH (2000) Customer exposure to gasoline vapors during refueling at service stations. Appl Occup Environ Hyg 15:677-680

Hoet P, De Smedt E, Ferrari M, Imbriani M, Maestri L, Negri S, De Wilde P, Lison D, Haufroid V (2009) Evaluation of urinary biomarkers of exposure to benzene: correlation with blood benzene and influence of confounding factors. Int Arch Occup Environ Health 82:985-995

Hornung RW, Reed LD (1990) Estimation of average concentration in the presence of non-detectable values. Appl Occup Environ Hyg 5:46-51

Inoue $\mathrm{O}$, Seiji $\mathrm{K}$, Watanabe T, Kasahara M, Nakatsuka $\mathrm{H}$, Yin $\mathrm{S}, \mathrm{Li}$ G, Cai S, Jin C, Ikeda M (1988) Mutual metabolic suppression between benzene and toluene in man. Int Arch Occup Environ Health 60:15-20

International Agency for Research on Cancer (IARC) (1987) IARC monographs on the evaluation of carcinogenic risks to humans, benzene, Lyon, France, vol 29, suppl 17

International Agency for Research on Cancer (IARC) (2000) IARC monographs on the evaluation of carcinogenic risks to humans. Some industrial chemicals, Lyon, France, vol 77, pp 227-266

Jin Y, Hein MJ, Deddens JA, Hines CJ (2011) Analysis of lognormally distributed exposure data with repeated measures and values below the limit of detection using SAS. Ann Occup Hyg 55:97-112

Jones K, Cocker J, Dodd LJ, Fraser I (2003) Factors affecting the extent of dermal absorption of solvent vapours: a human volunteer study. Ann Occup Hyg 47:145-150

Kawai T, Ukai H, Inoue O, Maejima Y, Fukui Y, Ohashi F, Okamoto S, Takada S, Sakurai H, Ikeda M (2008) Evaluation of biomarkers of occupational exposure to toluene at low levels. Int Arch Occup Environ Health 81:253-262

Keretetse GS, Laubscher PJ, Du Plessis JL, Pretorius PJ, Van Der Westhuizen FH, Van Deventer E, Van Dyk E, Eloff FC, Van Aarde MN, Du Plessis LH (2008) DNA damage and repair detected by the comet assay in lymphocytes of African petrol attendants: a pilot study. Ann Occup Hyg 52:653-662

Kirkeleit J, Riise T, Bråtveit M, Moen BE (2006a) Benzene exposure on a crude oil production vessel. Ann Occup Hyg 50:123-129

Kirkeleit J, Riise T, Bråtveit M, Pekari K, Mikkola J, Moen BE (2006b) Biological monitoring of benzene exposure during maintenance work in crude oil cargo tanks. Chem Biol Interact 164:60-67

Kirkeleit J, Riise T, Bråtveit M, Moen BE (2008) Increased risk of acute myelogenous leukemia and multiple myeloma in a historical cohort of upstream petroleum workers exposed to crude oil. Cancer Causes Control 19:13-23 
Lauwerys RR, Hoet P (1993) Industrial chemical exposure: guidelines for biological monitoring. FLS-phenylmercapturic acid in urine. Lewis Publishers, Boca Raton

Lewis JJ, Janetzki S, Schaed S, Panageas KS, Wang S, Williams L, Meyers M, Butterworth L, Livingston PO, Chapman PB, Houghton AN (2000) Evaluation of CD8(+) T-cell frequencies by the Elispot assay in healthy individuals and in patients with metastatic melanoma immunized with tyrosinase peptide. Int $\mathbf{J}$ Cancer 87:391-398

Lovreglio P, Barbieri A, Carrieri M, Sabatini L, Fracasso ME, Doria D, Drago I, Basso A, D'Errico MN, Bartolucci GB, Violante FS, Soleo L (2010) Validity of new biomarkers of internal dose for use in the biological monitoring of occupational and environmental exposure to low concentrations of benzene and toluene. Int Arch Occup Environ Health 83:341-356

Negri S, Bono R, Maestri L, Ghittori S, Imbriani M (2005) Highpressure liquid chromatographic-mass spectrometric determination of sorbic acid in urine: verification of formation of trans, trans-muconic acid. Chem Biol Interact 153-154:243-246

NIOSH (2003) NIOSH manual of analytical methods, 3rd edn (hydrocarbons, method: 1501). National Institute for Occupational Safety and Health, Cincinnati

Nomiyama K, Nomiyama H (1974) Respiratory elimination of organic solvents in man. Benzene, toluene, $n$-hexane, trichloroethylene, acetone, ethyl acetate and ethyl alcohol. Int Arch Arbeitsmed 32:85-91

Pekari K, Riekkola M-L, Aitio A (1989) Simultaneous determination of benzene and toluene in the blood using headspace gas chromatography. J Chromatogr 491:309-320

Pekari K, Vainiotalo S, Heikkilä P, Palotie A, Luotamo M, Riihimäki V (1992) Biological monitoring of occupational exposure to low levels of benzene. Scand J Work Environ Health 18:317-322
Periago JF, Prado C (2005) Evolution of occupational exposure to environmental levels of aromatic hydrocarbons in service stations. Ann Occup Hyg 49:233-240

Rekhadevi PV, Rahman MF, Mahboob M, Grover P (2010) Genotoxicity in filling station attendants exposed to petroleum hydrocarbons. Ann Occup Hyg 54(8):944-954

Riihimaki V, Pfaffli P (1978) Percutaneous absorption of solvent vapors in man. Scand J Work Environ Health 4:73-85

Runion HE (1988) Occupational exposure to potentially hazardous agents in the petroleum industry. Occup Med 3:431-444

Sorahan T, Nichols L, Harrington JM (2002) Mortality of United Kingdom oil refinery and petroleum distribution workers, 1951-1998. Occup Med 52:333-339

Steinsvåg K, Bråtveit M, Moen BE (2007) Exposure to carcinogens for defined job categories in Norway's offshore petroleum industry, 1970-2005. Occup Environ Med 64:250-258

Vainiotalo S, Kuusimäki L, Pekari K (2006) Exposure to MTBE, TAME and aromatic hydrocarbons during gasoline pump maintenance, repair and inspection. J Occup Health 48:347-357

Verma DK, Johnson DM, McLean JD (2000) Benzene and total hydrocarbon exposures in the upstream petroleum oil and gas industry. Am Ind Hyg Assoc J 61:255-263

Waidyanatha S, Rothman N, Fustinoni S, Smith MT, Hayes RB, Bechtold W, Dosemeci M, Guilan L, Yin S, Rappaport SM (2001) Urinary benzene as a biomarker of exposure among occupationally exposed and unexposed subjects. Carcinogenesis 22:279-286

Wong O, Raabe GK (2000) A critical review of cancer epidemiology in the petroleum industry, with a meta-analysis of a combined database of more than 350,000 workers. Regul Toxicol Pharmacol 32:78-98 